This item was submitted to Loughborough's Research Repository by the author.

Items in Figshare are protected by copyright, with all rights reserved, unless otherwise indicated.

\title{
A study of anion binding behaviour of 1,3-alternate thiacalix[4]arene-based receptors bearing urea moieties
}

\section{PLEASE CITE THE PUBLISHED VERSION}

http://dx.doi.org/10.1039/c6nj00923a

\section{PUBLISHER}

(C) Royal Society of Chemistry and the Centre National de la Recherche Scientifique

\section{VERSION}

AM (Accepted Manuscript)

\section{PUBLISHER STATEMENT}

This work is made available according to the conditions of the Creative Commons Attribution-NonCommercialNoDerivatives 4.0 International (CC BY-NC-ND 4.0) licence. Full details of this licence are available at: https://creativecommons.org/licenses/by-nc-nd/4.0/

\section{LICENCE}

CC BY-NC-ND 4.0

\section{REPOSITORY RECORD}

Rahman, Shofiur, Hirotsugu Tomiyasu, Hiroto Kawazoe, Jiang-Lin Zhao, Hang Cong, Xin-Long Ni, Xi Zeng, et al.. 2019. "A Study of Anion Binding Behaviour of 1,3-alternate Thiacalix[4]arene-based Receptors Bearing Urea Moieties". figshare. https://hdl.handle.net/2134/23386. 


\section{ARTICLE}

Cite this: DOI: $10.1039 /$ xoxxooooox

Received ooth January 2012, Accepted ooth January 2012

DOI: $10.1039 / \times 0 \times x 00000 x$

www.rsc.org/

\section{A study of anion binding behaviour of 1,3-alternate thiacalix[4]arene-based receptors bearing urea moieties $\dagger$}

\author{
Shofiur Rahman,${ }^{a, b}$ Hirotsugu Tomiyasu, ${ }^{a}$ Hiroto Kawazoe, ${ }^{a}$ Jiang-Lin Zhao, ${ }^{a}$ Hang \\ Cong, ${ }^{c}$ Xin-Long Ni, ${ }^{c}$ Xi Zeng, ${ }^{c}$ Mark R. J. Elsegood, ${ }^{d}$ Thomas G. Warwick, ${ }^{d}$ Simon J. \\ Teat, $^{e}$ Carl Redshaw, ${ }^{f}$ Paris E. Georghiou ${ }^{b}$ and Takehiko Yamato* ${ }^{a}$
}

\begin{abstract}
Three novel thiacalix[4]arene receptors $\mathbf{4}_{\mathbf{a} \sim \mathbf{c}}$ each with a 1,3-alternate conformation and possessing two urea moieties linking various phenyl groups substituted with either para electron-donating or withdrawing groups have been synthesized. The binding properties of these receptors were investigated by means of ${ }^{1} \mathrm{H}$ NMR spectroscopy and UV-vis absorption titration experiments using various anions. The structures and complexation energies were also studied by density functional theory (DFT) methods. The results suggested that receptor $\mathbf{4}_{\mathfrak{c}}$, which possesses two $p$-(trifluoromethyl)phenyl ureido moieties, can complex most efficiently in the urea cavity and exhibits high selectivity towards $\mathrm{F}^{-}$and $\mathrm{AcO}^{-}$ions.
\end{abstract}

of cations, and also due to the large variety of geometries available, ${ }^{6}$ some anions are spherical $\left(\mathrm{F}^{-}, \mathrm{Cl}^{-}, \mathrm{Br}^{-}, \mathrm{I}^{-}\right)$others are trigonal or $\mathrm{Y}$-shaped $\left(\mathrm{AcO}^{-}\right)$and others are tetrahedral $\left(\mathrm{H}_{2} \mathrm{PO}_{4}^{-}\right.$

\section{Introduction}

Calix $[n]$ arenes $^{1}$ have three-dimensional tuneable shapes and are used as molecular building blocks with potentially many applications in supramolecular chemistry. Thiacalix[4]arenes ${ }^{2,3}$ are calix $[n]$ arenes in which the phenolic groups are bridged by sulfur atoms instead of methylene groups, and have received much recent attention for potential applications in various fields across chemistry, biology and environmental science. Various anions such as $\mathrm{F}^{-}$(e.g., in dental caries prevention, in inhalation anesthetics and in the treatment of osteoporosis) also play fundamental roles in biological, medicinal, catalysis, and environmental chemistry. ${ }^{4}$ The design and synthesis of anionselective receptors ${ }^{5}$ is more difficult than that of cationselective receptors. This is due to some unique features of anions such as their much larger sizes in comparison with those

\footnotetext{
${ }^{a}$ Department of Applied Chemistry, Faculty of Science and Engineering, Saga University, Honjo-machi 1, Saga 840-8502 Japan, E-mail: yamatot@cc.saga-u.ac.jp

${ }^{b}$ Department of Chemistry, Memorial University of Newfoundland, St. John's, Newfoundland and Labrador A1B 3X7, Canada

${ }^{c}$ Department Key Laboratory of Macrocyclic and Supramolecular Chemistry of Guizhou Province, Guizhou University, Guiyang, Guizhou, 550025, China

${ }^{d}$ Chemistry Department, Loughborough University, Loughborough LE11 3TU, UK.

${ }^{e}$ ALS, Berkeley Lab, 1 Cyclotron Road, Bereleley, CA 94720, USA

${ }^{f}$ Department of Chemistry, The University of Hull, HU6 7RX, UK

†Electronic Supplementary Information (ESI) available: Details of the ${ }^{1} \mathrm{H} /{ }^{13} \mathrm{C} N M R$ spectra, ${ }^{1} \mathrm{H}$ NMR spectroscopic and UV-vis titration experimental data and computational studies. See DOI: 10.1039/b000000x/
} ), etc.. Anion recognition using artificially-designed receptors ${ }^{6}$ based on calix[n]arenes is an important research topic in the area of supramolecular chemistry. Calix $[n]$ arene urea derivatives are capable of effectively recognizing and sensing important anions via hydrogen-bonding interactions between the anions and the urea $\mathrm{NH}$ protons. ${ }^{7,8}$

Lhoták and co-workers ${ }^{9}$ have reported anion receptors based on either upper-rim substituted calix[4]arenes or thiacalix[4]arenes which contain two $p$-nitrophenyl or $p$-tolyl urea moieties. ${ }^{9 \mathrm{a} \sim \mathrm{c}, \mathrm{h}}$ These anion receptors exhibited effective recognition abilities towards selected anions in common organic solvents. Recently, Kumar and co-workers reported an anion receptor based on a calix[4]arene in a 1,3-alternate conformation and bearing containing two $p$-nitrophenyl-ureido moieties. ${ }^{10}$ This compound exhibited strong binding and good selectivity towards $\mathrm{Cl}^{-}$ion due to strong hydrogen bonding between the $\mathrm{Cl}^{-}$ion and the $\mathrm{N}-\mathrm{H}$ protons, both in THF or chloroform solutions. However, investigations concerning the influence on the acidity of the urea protons by either electrondonating or electron-withdrawing groups located on the $p$ position of phenyl groups of urea moieties in analogous thiacalix[4]arenes and the binding of various anions have received scant attension. ${ }^{11 \mathrm{j}}$

In this article, we report the synthesis of three novel thiacalix[4]arenes receptors $\mathbf{4}_{\mathbf{a} \sim \mathbf{c}}$ with a 1,3-alternate conformation and possessing two urea moieties linking various 
phenyl groups bearing either para electron-donating or electron-withdrawing groups, together with two benzyl groups at the opposite sides of the thiacalix[4]arene cavity. ${ }^{11}$ In our studies, the complexation properties of $\mathbf{4}_{\mathbf{a} \sim \mathbf{c}}$ towards $\mathrm{F}^{-}, \mathrm{Cl}^{-}, \mathrm{Br}^{-}$, $\mathrm{I}^{-}, \mathrm{AcO}^{-}$and $\mathrm{H}_{2} \mathrm{PO}_{4}^{-}$ions were investigated by ${ }^{1} \mathrm{H}-\mathrm{NMR}$ spectroscopy (with $\mathbf{4}_{\mathbf{a} \sim \mathbf{c}}$ ) and UV-vis absorption (with $\mathbf{4}_{\mathbf{c}}$ ) titration experiments. Furthermore, the structures and complexation energies for all complexes of the receptors $\mathbf{4}_{\mathbf{a} \sim \mathbf{c}}$ with various anions were also determined by theoretical studies using DFT methods.

\section{Results and discussions}

\section{Synthesis}

O-Alkylation of 1,3-alternate-1 was conducted using 2 equivalents of bromoacetamide in the presence of 2 equivalents of $\mathrm{Cs}_{2} \mathrm{CO}_{3}$ according to the reported procedure, and afforded the desired 1,3alternate-2 in $60 \%$ yield. ${ }^{12}$ The amide reduction of 1,3-alternate-2 was carried out with a large excess of $\mathrm{BH}_{3} / \mathrm{THF}$ solution, and afforded the desired 1,3-alternate-3 in $65 \%$ yield. The condensation of 1,3-alternate-3 with 2.2 equivalents of the appropriate isocyanate in $\mathrm{CH}_{2} \mathrm{Cl}_{2}$ furnished the receptors $\mathbf{4}_{\mathbf{a} \sim \mathbf{c}}$ in good yields (Scheme 1). The ${ }^{1} \mathrm{H}$ NMR spectrum of receptors $\mathbf{4}_{\mathbf{a} \sim \mathbf{c}}$ in $\mathrm{CDCl}_{3}$ exhibits the characteristics of a 1,3-alternate conformation such as two singlets (18H each) for the tert-butyl protons, two triplets $(4 \mathrm{H}$ each) for the $\mathrm{OCH}_{2} \mathrm{CH}_{2}$ - protons, two singlets (4H each) for the aromatic protons and two singlets ( $2 \mathrm{H}$ each) for the four urea $\mathrm{NH}$ protons. Moreover, concentration dependence of the ${ }^{1} \mathrm{H}$ NMR chemical shifts of the urea protons in receptor $\mathbf{4}_{\mathbf{c}}$ was not observed (Fig. S11). This (lack of) observation indicates that receptor $\mathbf{4}_{\mathbf{c}}$ has strong intramolecular hydrogen bonds between the two urea groups linking the $p$ (trifluoromethyl)phenyl moieties. The molecular structure of receptor $\mathbf{4}_{\mathbf{a}}$ was also verified by X-ray crystallographic analysis (Fig. $1, \mathbf{S} 12)$. Receptor $\mathbf{4}_{\mathbf{a}}$ was recrystallized from a mixture of
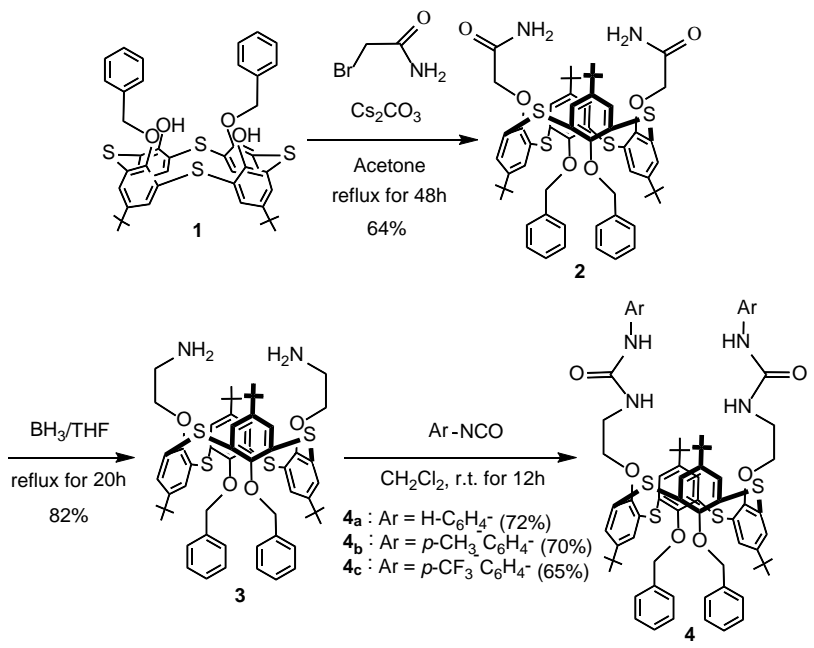

Scheme 1 Synthesis of receptors 1,3-alternate- $\mathbf{4}_{\mathbf{a} \sim c}$.

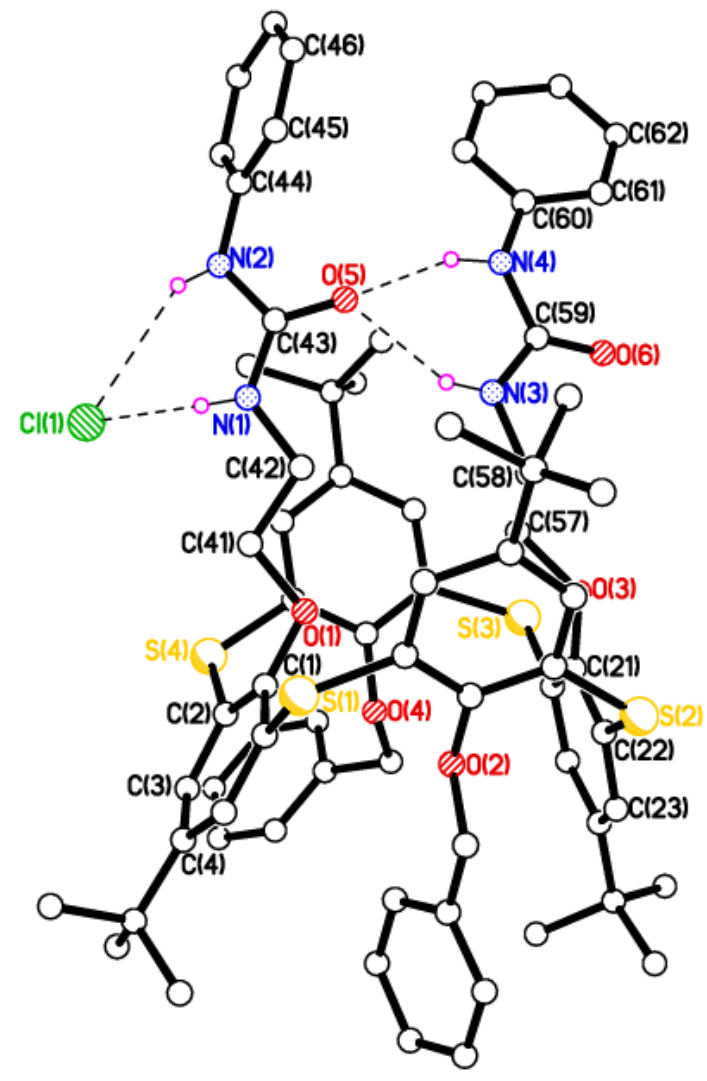

Fig. 1 X-ray crystal structure of receptor $\mathbf{4}_{\mathrm{a}} \cdot \mathrm{Cl}^{-}$. H-bonds shown as dashed lines. One of four similar molecules in the asymmetric unit is shown in two orientations rotated by approx. $90^{\circ}$. $\mathrm{H}$ atoms not involved in H-bonding, minor disorder components, and solvent of crystallization are omitted for clarity. Guest used: tetrabutylammonium (TBA) salt.

$\mathrm{CHCl}_{3}-\mathrm{CH}_{3} \mathrm{CN}(3: 2, \mathrm{v} / \mathrm{v})$ by slow evaporation. These results indicate that receptor $\mathbf{4}_{\mathrm{a}}$ adopts the 1,3-alternate conformation in the solid state. In case of receptor $\mathbf{4}_{\mathbf{a}}$, there are four thiacalixarenes, two $\mathrm{Cl}^{-}$ions, two tetrabutylammonium ions, one chloroform and two acetonitrile molecules in the asymmetric unit. Interestingly, it was found that the two urea groups approach each other and are oriented in parallel due to the existence of dual intramolecular hydrogen bonding (in the case of receptor $\mathbf{4}_{\mathbf{a}}$, for the molecule shown: N(3)$\mathrm{H}(3) \cdots \mathrm{O}(5)$ 2.13(3); $\mathrm{N}(4)-\mathrm{H}(4) \cdots \mathrm{O}(5) 2.17(3) \AA$; for the second molecule: $\mathrm{N}(1 \mathrm{~A})-\mathrm{H}(1 \mathrm{~A}) \cdots \mathrm{O}(6 \mathrm{~A}) \quad 2.15(3), \mathrm{N}(2 \mathrm{~A})-\mathrm{H}(2 \mathrm{~A}) \cdots \mathrm{O}(6 \mathrm{~A})$ 2.20(3) $\AA$; for the third molecule: $\mathrm{N}(3 \mathrm{~B})-\mathrm{H}(3 \mathrm{~B}) \cdots \mathrm{O}(5 \mathrm{~B})$ 2.30(3), $\mathrm{N}(4 \mathrm{~B})-\mathrm{H}(4 \mathrm{~B}) \cdots \mathrm{O}(5 \mathrm{~B}) 2.17(2) \AA$; for the fourth molecule: $\mathrm{N}(1 \mathrm{C})-$ $\mathrm{H}(1 \mathrm{C}) \cdots \mathrm{O}(6 \mathrm{C})$ 2.31(3), $\mathrm{N}(2 \mathrm{C})-\mathrm{H}(2 \mathrm{C}) \cdots \mathrm{O}(6 \mathrm{C}) 2.27(3) \AA$ ) (Fig. 1, $\mathrm{S} 12)$. Moreover, in the case of receptor $\mathbf{4}_{\mathbf{a}}$, pairs of calixarene molecules are linked via four $\mathrm{H}$-bonds between two urea $\mathrm{NH}$ moieties on each calixarene and $\mathrm{Cl}^{-}$ion. 
Table 1. Association constants ${ }^{a}$ of receptors $\mathbf{4}_{\text {arc }}$ with anions. ${ }^{b}$

\begin{tabular}{cccccccc}
\hline & & & \multicolumn{5}{c}{ Association constant $\boldsymbol{K}_{\mathrm{a}}\left[\mathrm{M}^{-1}\right]$} \\
Host & $\mathrm{R}$ & $\begin{array}{c}\mathrm{F}^{-} \\
\text {Spherical }\end{array}$ & $\begin{array}{c}\mathrm{Cl}^{-} \\
\text {Spherical }\end{array}$ & $\begin{array}{c}\mathrm{Br}^{-} \\
\text {Spherical }\end{array}$ & $\begin{array}{c}\mathrm{I}^{-} \\
\text {Spherical }\end{array}$ & $\begin{array}{c}\mathrm{AcO}^{-} \\
\text {Y-shape }\end{array}$ & $\begin{array}{c}\mathrm{H}_{2} \mathrm{PO}_{4}^{-} \\
\text {Tetrahedral }\end{array}$ \\
\hline $\mathbf{4}_{\mathbf{a}}$ & $\mathrm{H}$ & $6,745 \pm 472$ & $2,937 \pm 206$ & $1,453 \pm 102$ & $410 \pm 29$ & $6,305 \pm 441$ & $2,727 \pm 191$ \\
$\mathbf{4}_{\mathbf{b}}$ & $\mathrm{Me}$ & $3,550 \pm 286$ & $1,557 \pm 109$ & $734 \pm 51$ & $203 \pm 14$ & $3,033 \pm 212$ & $1,338 \pm 94$ \\
$\mathbf{4}_{\mathbf{c}}$ & $\mathrm{CF}_{3}$ & $13,950 \pm 977$ & $6,590 \pm 461$ & $2,920 \pm 204$ & $883 \pm 62$ & $12,878 \pm 901$ & $5,790 \pm 405$ \\
\hline
\end{tabular}

${ }^{a}$ Measured in $\mathrm{CDCl}_{3}-\mathrm{CD}_{3} \mathrm{CN}\left(10: 1\right.$, v/v) at $298 \mathrm{~K}$ by the ${ }^{1} \mathrm{H}$ NMR titration method using the chemical-shift change of the $\mathrm{NH}_{\mathrm{a}}$ proton (Fig. S13-S49); host concentration was $4.0 \times 10^{-3} \mathrm{M}^{b}$ Guests used: TBA salts.

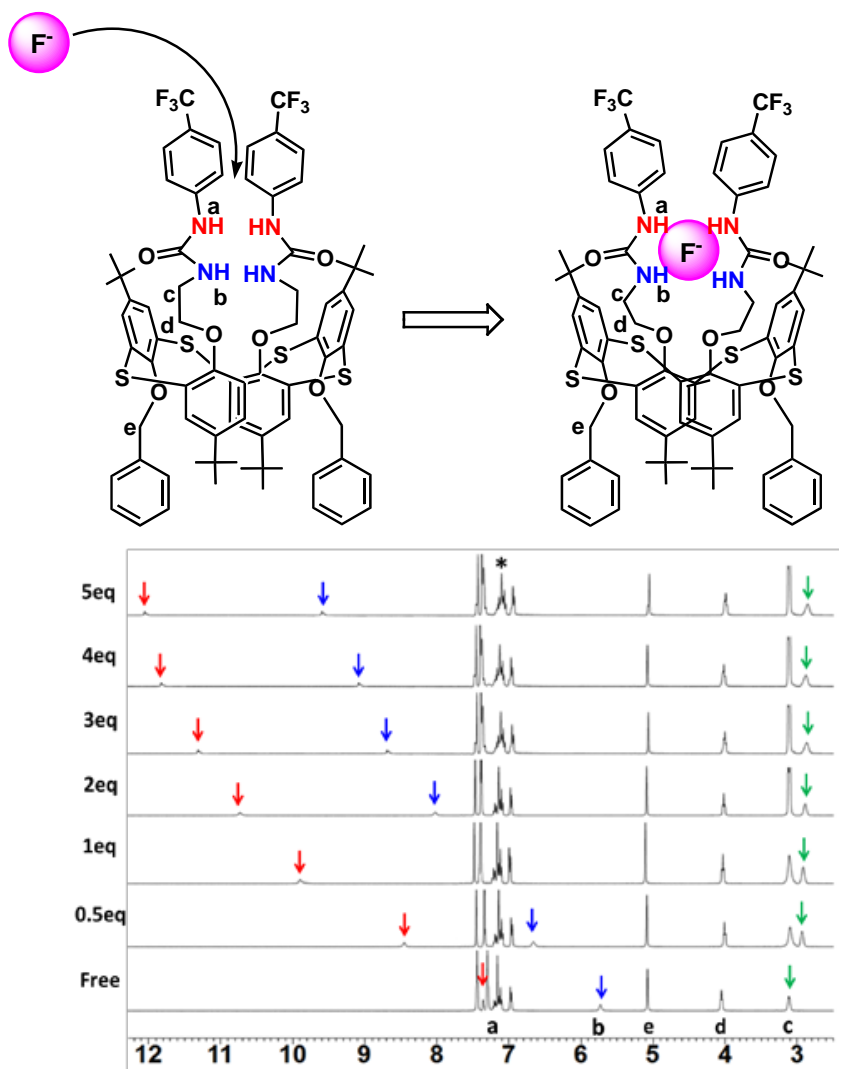

Fig. 2 Binding mode of receptor $4 \mathrm{c}$ upon addition of $\mathrm{F}^{-}$ion at $298 \mathrm{~K}$ as TBA salts and partial ${ }^{1} \mathrm{H}$ NMR spectra of $\mathbf{4}_{\mathrm{c}}\left(4.0 \times 10^{-3} \mathrm{M}\right)$ in $\mathrm{CDCl}_{3}-\mathrm{CD}_{3} \mathrm{CN}(10: 1$, $\mathrm{v} / \mathrm{v}$ ) upon addition of $\mathrm{F}^{-}$ion at $298 \mathrm{~K}$.

\section{Binding studies}

The binding properties of receptors $\mathbf{4}_{\mathbf{a} \sim \mathbf{c}}$ in the presence of various anions as their tetrabutylammonium (TBA) salts, in $\mathrm{CDCl}_{3}-\mathrm{CD}_{3} \mathrm{CN}$ (10:1) solution, were investigated by means of ${ }^{1} \mathrm{H}-\mathrm{NMR}$ titration spectroscopic experiments. As shown in Fig. 2, for the complexation of $\mathrm{F}^{-}$ion with receptor $\mathbf{4}_{\mathrm{c}}$, the signals for the $\mathrm{NH}_{\mathrm{a}}$ protons (red)

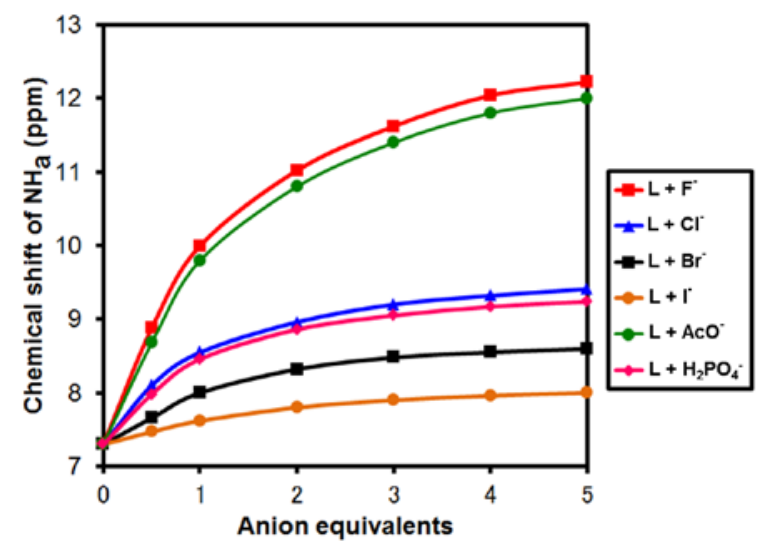

Fig. 3 Titration curves of receptor $\mathbf{4}_{\mathbf{c}}$ with various anions as their TBA salts in $\mathrm{CDCl}_{3}-\mathrm{CD}_{3} \mathrm{CN}(10: 1, \mathrm{v} / \mathrm{v})$ at $298 \mathrm{~K}$.

progressively shifted downfield by $4.55 \mathrm{ppm}$ ( $\delta=7.35$ to $11.9 \mathrm{ppm}$ ) until five equivalents of $\mathrm{F}^{-}$ion was added. On the other hand, the signals for the $\mathrm{NH}_{\mathrm{b}}$ protons (blue) progressively shifted downfield by $3.88 \mathrm{ppm}$ ( $\delta=5.72$ to $9.60 \mathrm{ppm}$ ) until five equivalents of $\mathrm{F}^{-}$ion were added. These results are strongly suggestive of $\mathrm{F}^{-}$ion recognition by receptor $\mathbf{4}_{\mathbf{c}}$ via hydrogen-bonding interactions between the $\mathrm{F}^{-}$ion and the $\mathrm{N}-\mathrm{H}$ protons. The titration curves shown in Fig. 2, 3 (for $\mathbf{4}_{\mathbf{c}}$ ) and Fig. S13-S49 show that further addition of various anions to the solution of each receptors $\mathbf{4}_{\mathbf{a} \sim \mathbf{c}}$ in $\mathrm{CDCl}_{3}$ solution, resulted in clear downfield shifts of the ${ }^{1} \mathrm{H}$ NMR signals of the $\mathrm{NH}_{\mathrm{a}}$ protons. All of the results obtained clearly suggest that anion recognition by the receptors is via hydrogen-bonding interactions between the anion and the $\mathrm{NH}$ protons. In particular, as shown in Fig. 2, receptor $\mathbf{4}_{\mathrm{c}}$ exhibited the highest selectivity amongst all of the anions tested, toward $\mathrm{F}^{-}$and $\mathrm{AcO}^{-}$ions. $K_{\mathrm{a}}$ values for receptors $\mathbf{4}_{\mathbf{a} \sim \mathbf{c}}$ and the anions tested were determined by ${ }^{1} \mathrm{H}$ NMR spectroscopic titration experiments. ${ }^{13 a}$ (Table 1). These results suggest that the $K_{\mathrm{a}}$ values are influenced by the electron-donating or electron-withdrawing groups located at the $p$-position of the phenyl 


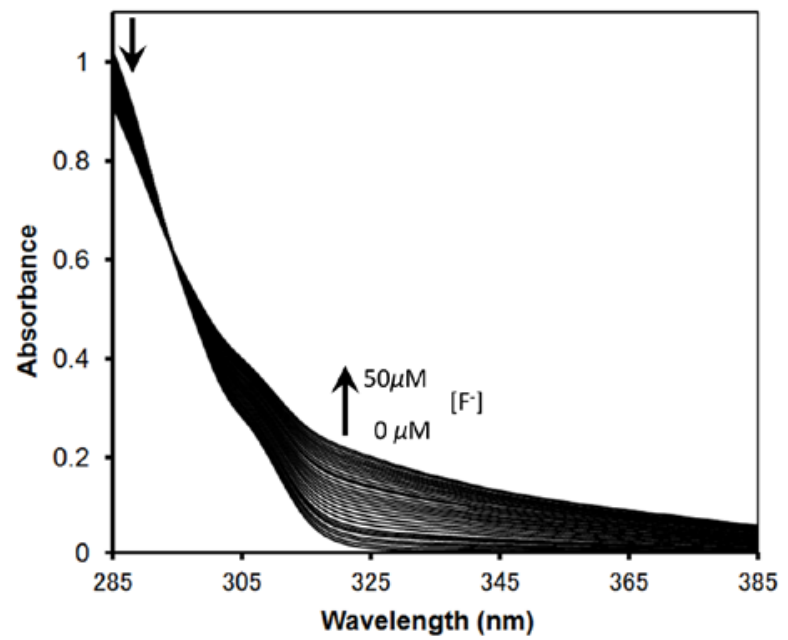

Fig. $4 \mathrm{UV}$-vis absorption spectra of receptor $\mathbf{4}_{\mathrm{c}}(2.5 \mu \mathrm{M})$ upon the addition of $\mathrm{F}^{-}(0-50 \mu \mathrm{M})$ at $298 \mathrm{~K}$ as a TBA salt in $\mathrm{CH}_{2} \mathrm{Cl}_{2}$.

Table 2. Association constants ${ }^{a}$ of receptors $\mathbf{4}_{\mathrm{c}}$ with anions. ${ }^{b}$

\begin{tabular}{ccccc}
\hline Anion & $\mathrm{F}^{-}$ & $\mathrm{Cl}^{-}$ & $\mathrm{AcO}^{-}$ & $\mathrm{H}_{2} \mathrm{PO}_{4}^{-}$ \\
\hline$K_{\mathrm{a}}\left[\mathrm{M}^{-1}\right]$ & $465,405 \pm 32,578$ & $9,060 \pm 634$ & $418,495 \pm 29,519$ & $8,258 \pm 578$ \\
\hline
\end{tabular}

${ }^{a}$ Measured in $\mathrm{CH}_{2} \mathrm{Cl}_{2}$ at $298 \mathrm{~K}$ by UV-vis titration method (Fig. S50S58); host concentration was $2.5 \mu \mathrm{M} .{ }^{b}$ Guests used: TBA salts.

ureido moieties. The $K_{\mathrm{a}}$ values for $\mathbf{4}_{\mathrm{c}}$ having the electronwithdrawing $\mathrm{CF}_{3}$ groups on the phenyl ureido moieties, were greater than those for the other two receptors. The $K_{\mathrm{a}}$ values for $\mathbf{4}_{\mathbf{b}}$ which had the electron-donating $\mathrm{CH}_{3}$ groups on the ureido phenyl moieties were lower than those for $\mathbf{4}_{a}$ and $\mathbf{4}_{b}$. Therefore, the introduction of electron-withdrawing groups at the $p$-position of the phenyl ureido groups appears to increase the acidity of the urea protons, and hence enhance the anion-binding ability through hydrogen-bonding interactions. Furthermore, receptor $\mathbf{4}_{\mathrm{c}}$ had the highest $K_{\mathrm{a}}$ values of all three receptors with each of the anions tested and also had the most effective recognition ability toward $\mathrm{F}^{-}$and $\mathrm{AcO}^{-}$ions. Further complexation studies of $\mathbf{4}_{\mathbf{c}}$ with $\mathrm{F}^{-}, \mathrm{Cl}^{-}, \mathrm{AcO}^{-}$and $\mathrm{H}_{2} \mathrm{PO}_{4}^{-}$ions were carried out using UV-vis spectroscopic titration experiments. Receptor $\mathbf{4}_{\mathrm{c}}(2.5 \mu \mathrm{M})$ exhibits a broad absorption band at $295 \mathrm{~nm}$ in its UV-vis absorption spectrum. Upon addition of $\mathrm{F}^{-}$ion $(0-50 \mu \mathrm{M})$ to the solution of $\mathbf{4}_{\boldsymbol{c}}$, Fig. 4 reveals a gradual decrease in the absorption of the band at $288 \mathrm{~nm}$ with a simultaneous increase in the absorption at $320 \mathrm{~nm}$ and a clear isosbestic point at $295 \mathrm{~nm}$. From the above, it is clear that receptor $\mathbf{4}_{\mathbf{c}}$ bearing the $\mathrm{CF}_{3}$ groups has the most effective recognition ability toward $\mathrm{F}^{-}$ions. A Job's plot for the binding between the receptor $\mathbf{4}_{\mathrm{c}}$ and $\mathrm{F}^{-}$ion reveals a $1: 1$ stoichiometry (Fig. S52), and the $K_{\mathrm{a}}$ for the complexation ${ }^{13 \mathrm{~b}}$ of receptor $\mathbf{4}_{\mathrm{c}}$ with $\mathrm{F}^{-}$ion was determined to be $465,405 \pm 32,578 \mathrm{M}^{-1}$ by the UV-vis titrations in $\mathrm{CH}_{2} \mathrm{Cl}_{2}$ solution (Fig. S51). These results strongly suggested that $\mathrm{F}^{-}$ion recognition by receptor $\mathbf{4}_{\mathrm{c}}$ was via a hydrogen-bonding interaction between $\mathrm{F}^{-}$ion and $\mathrm{NH}$ protons, as shown in Fig. 4. The $K_{\mathrm{a}}$ values obtained by similar UV-vis titration

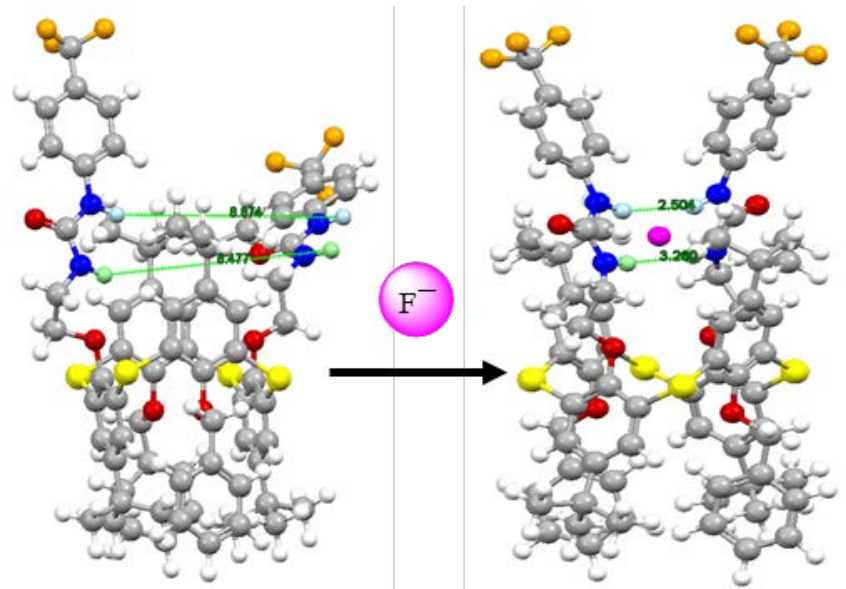

Fig. 5 Geometry-optimized (ball-and-stick) structures of: Left: $\mathbf{4}_{\mathrm{c}}$; Right: 1;1 complex of $\mathbf{4}_{\mathbf{c}} \supset \mathrm{F}^{-}$. Colour code: $\mathrm{F}^{-}=$magenta; nitrogen = blue; $\mathrm{NH}_{\mathrm{a}}=$ light blue; $\mathrm{NH}_{\mathrm{b}}=$ light green; sulphur = yellow; $\mathrm{CF}_{3}($ fluoride $)=$ orange; and oxygen atom $=$ red.

experiments of $\mathbf{4}_{\mathbf{c}}$ with the other anions are summarized in Table 2 . To further investigate the binding properties of receptors $\mathbf{4}_{\mathbf{a} \sim \mathbf{c}}$ with the anions tested, a computational study was carried out. The individual structures for all studies in the gas-phase were fully geometry-optimized using Gaussian $09^{14}$ with the B3LYP level of DFT and the 3-21G basis set. Significant changes were observed for the distances between two urea $\mathrm{NH}$ moieties on each of the receptors $\mathbf{4}_{\mathbf{a} \sim \mathbf{c}}$ in their anion complexes. The conformation changes for $\mathbf{4}_{\mathbf{c}}$ upon 1:1 complexation with $\mathrm{F}^{-}$ion can be seen in Fig. 5 (more precise details for the computation studies for receptors $\mathbf{4}_{\mathbf{a} \sim \mathbf{c}}$ with the different anions are shown in Fig. S59-S94). Fig. 5 shows the computed structure (right) of the 1:1 complex of $\mathbf{4}_{\mathbf{c}}$ with $\mathrm{F}^{-}$ion. Because of the hydrogen-bonding between the $\mathrm{F}^{-}$ion and two urea $\mathrm{NH}$ protons, distances between two urea $\mathrm{NH}$ moieties $\left(\mathrm{NH}_{\mathrm{a}} \cdots \mathrm{NH}_{\mathrm{a}^{\prime}}\right.$ and $\mathrm{NH}_{\mathrm{b}} \cdots \mathrm{NH}_{\mathrm{b}^{\prime}}$ ) on two $p$-(trifluoromethyl)phenyl ureido moieties decrease from 8.783 to 2.530 ( $\AA$ ) and from 8.379 to 3.251 ( $\AA$ ), respectively. This also strongly supports the experimental evidence obtained for the formation of a 1:1 $\left(\mathbf{4}_{\mathbf{c}} \supset \mathrm{F}^{-}\right)$complex. The calculated complexation energies $\left(\Delta E \mathrm{~kJ} \mathrm{~mol}^{-1}\right)$ for receptors $\boldsymbol{4}_{\mathbf{a} \sim \mathrm{c}}$ with the anion complexes are shown in Table 3. The trend for the complexation energies for $\mathbf{4}_{\mathbf{a} \sim \mathbf{c}}$ are in the order: $\mathrm{F}^{-}>\mathrm{AcO}^{-}>\mathrm{H}_{2} \mathrm{PO}_{4}^{-}>\mathrm{Cl}^{-}>\mathrm{Br}^{-}>\mathrm{I}^{-}$, which is in agreement with the trend observed for the observed complexation data obtained by means of ${ }^{1} \mathrm{H}$ NMR spectroscopy and UV-vis absorption titration experiments.

\section{Conclusion}

In summary, three novel receptors $\mathbf{4}_{\mathbf{a} \sim \mathbf{c}}$ bearing a thiacalix[4]arene in a 1,3-alternate conformation have been synthesized. These receptors possess two ureas moieties linking various aryl groups bearing electron-donating or -withdrawing groups at their $p$-positions, which act as anion-binding sites and two benzyl groups at the opposite side of thiacalix[4]arene cavity. The binding of various anions at the two urea moieties was investigated by using ${ }^{1} \mathrm{H}$ NMR, UV-vis absorption titration experiments. It was found that receptor $\mathbf{4}_{\mathrm{c}}$ has a much higher 
affinity towards all of the selected anions and especially for $\mathrm{F}^{-}$and $\mathrm{AcO}^{-}$ions.

\section{Experimental Section}

\section{General}

All melting points were determined with a Yanagimoto MP-S1 melting point apparatus. ${ }^{1} \mathrm{H}-\mathrm{NMR}$ spectra were determined at $300 \mathrm{MHz}$ with a Nippon Denshi JEOL FT-300 NMR spectrometer with TMS as an internal reference; J-values are given in Hz. UV-vis spectra were measured with a Shimadzu 240 spectrophotometer. Mass spectra were obtained on a Nippon Denshi JMS-01SG-2 mass spectrometer at an ionization energy of $70 \mathrm{eV}$ using a direct inlet system through GLC. Elemental analyses were performed by Yanaco MT-5.

\section{Materials}

Unless otherwise stated, all other reagents used were purchased from commercial sources and were used without further purification. Compounds $\mathbf{1},{ }^{11 \mathrm{~d}, 12} \mathbf{2}^{12}$ and $\mathbf{3}^{12}$ were prepared following the reported procedures.

\section{Preparations}

$\mathbf{4}_{\mathrm{a}}$ : To a solution of compound 3 (150 $\mathrm{mg}, 0.166 \mathrm{mmol}$ ) in $\mathrm{CH}_{2} \mathrm{Cl}_{2}(10 \mathrm{~mL})$ was added phenyl isocyanate $(44 \mathrm{mg}, 0.37$ $\mathrm{mmol}$ ) and the mixture was stirred at room temperature for $24 \mathrm{~h}$ under argon. The resulting precipitate was collected by filtration, washed with $\mathrm{CH}_{3} \mathrm{OH}$ to give receptor $\mathbf{4}_{\mathbf{a}}$ as a white solid. Recrystallization from $\mathrm{CHCl}_{3}-\mathrm{CH}_{3} \mathrm{OH}$ (2:1) gave receptor $\mathbf{4}_{\mathbf{a}}$ (146 $\mathrm{mg}, 72 \%$ ) as a white solid. M.p. $200-202{ }^{\circ} \mathrm{C}$. IR: $v_{\max }(\mathrm{KBr}) / \mathrm{cm}^{-1}: 3220,2958,1683,1542,1439,1214,1206$, 1137, 994, 812 and 760. ${ }^{1} \mathrm{H}$ NMR (300 MHz, $\left.\mathrm{CDCl}_{3}\right): \delta=0.85$ $(18 \mathrm{H}, \mathrm{s}, t \mathrm{Bu} \times 2), 1.22(18 \mathrm{H}, \mathrm{s}, t \mathrm{Bu} \times 2), 3.05\left(4 \mathrm{H}, \mathrm{br}, \mathrm{CH}_{2} \mathrm{NH}\right.$ $\times 2), 4.01\left(4 \mathrm{H}, \mathrm{br}, \mathrm{OCH}_{2} \times 2\right), 5.08\left(4 \mathrm{H}, \mathrm{s}, \mathrm{OCH}_{2} \times 2\right), 5.56$ $(2 \mathrm{H}, \mathrm{s}, \mathrm{NH} \times 2), 6.90-7.22$. (20H, m, Phenyl-H× 20), $7.09(4 \mathrm{H}$, s, $\mathrm{Ar}-H \times 4), 7.18(2 \mathrm{H}, \mathrm{s}, \mathrm{NH} \times 2)$ and $7.41(4 \mathrm{H}, \mathrm{s}, \mathrm{Ar}-H \times 4)$ ppm. ${ }^{13} \mathrm{C}$ NMR (100 MHz, $\left.\mathrm{CDCl}_{3}\right): \delta=30.9\left(\mathrm{CH}_{3}\right), 31.0\left(\mathrm{CH}_{3}\right)$, $33.9\left(\mathrm{C}\left(\mathrm{CH}_{3}\right)_{3}\right), 34.1\left(\mathrm{C}\left(\mathrm{CH}_{3}\right)_{3}\right), 40.9\left(\mathrm{CH}_{2}\right), 70.8\left(\mathrm{OCH}_{2}\right), 72.0$ $\left(\mathrm{OCH}_{2}\right), 124.6$ (ArC), 125.9 (ArC), 126.2 (ArC), 126.3 (ArC), 126.5 (ArC), 126.7 (ArC), 128.0 (ArC), 128.3 (ArC), 128.5 (ArC), 128.6 (ArC), 128.8 (ArC), 129.0 (ArC), 129.1 (ArC), 129.3 (ArC), 130.0 (ArC), 132.0 (ArC), 135.2 (ArC), 142.8 (ArC), 146.1 (ArC) and 155.4 (CO) ppm. FABMS: $m / z$ : $1224.50\left(\mathrm{M}^{+}\right) . \mathrm{C}_{72} \mathrm{H}_{80} \mathrm{~N}_{4} \mathrm{O}_{6} \mathrm{~S}_{4}(1224.50)$ : calcd C 70.55, H 6.58, N 4.57. Found: C 70.52, H 6.57, N 4.58.

$\mathbf{4}_{\mathbf{b}}$ : To a solution of compound 3 (150 $\left.\mathrm{mg}, 0.166 \mathrm{mmol}\right)$ in $\mathrm{CH}_{2} \mathrm{Cl}_{2}(10 \mathrm{~mL})$ was added $p$-tolyl isocyanate (48 $\mathrm{mg}, 0.37$ $\mathrm{mmol}$ ) and the mixture was stirred at room temperature for $24 \mathrm{~h}$ under argon. The resulting precipitate was collected by filtration, washed with $\mathrm{CH}_{3} \mathrm{OH}$ to give receptor $\mathbf{4}_{\mathbf{b}}$ as a white solid. Recrystallization from $\mathrm{CHCl}_{3}-\mathrm{CH}_{3} \mathrm{OH}$ (3:1) gave receptor $\mathbf{4}_{\mathbf{b}}$ (146 $\mathrm{mg}, 70 \%$ ) as white solid. M.p. 203-204 ${ }^{\circ} \mathrm{C}$. IR: $v_{\max }(\mathrm{KBr}) / \mathrm{cm}^{-1}:$ 3301, 2946, 1605, 1583, 1426, 1211, 1196 , 1123, 1016, 889 and 802. ${ }^{1} \mathrm{H}$ NMR (300 MHz, $\left.\mathrm{CDCl}_{3}\right): \delta=$
$0.82(18 \mathrm{H}, \mathrm{s}, t \mathrm{Bu} \times 2), 1.22(18 \mathrm{H}, \mathrm{s}, t \mathrm{Bu} \times 2), 2.29\left(6 \mathrm{H}, \mathrm{s}, C_{3}\right.$ $\times 2), 3.06\left(4 \mathrm{H}, \mathrm{br}, \mathrm{CH}_{2} \mathrm{NH} \times 2\right), 4.03\left(4 \mathrm{H}, \mathrm{br}, \mathrm{OCH}_{2} \times 2\right), 5.05$ $\left(4 \mathrm{H}, \mathrm{s}, \mathrm{OCH}_{2} \times 2\right), 5.50(2 \mathrm{H}, \mathrm{br}, \mathrm{NH} \times 2), 6.86(2 \mathrm{H}, \mathrm{s}, \mathrm{NH} \times 2)$, 6.96-7.18. (18H, m, Phenyl-H× 18), $7.10(4 \mathrm{H}, \mathrm{s}, \mathrm{Ar}-H \times 4)$ and $7.41(4 \mathrm{H}, \mathrm{s}, \mathrm{Ar}-\mathrm{H} \times 4) \mathrm{ppm} .{ }^{13} \mathrm{C} \mathrm{NMR}\left(100 \mathrm{MHz}, \mathrm{CDCl}_{3}\right)$ : $\delta=20.0\left(\mathrm{CH}_{3}\right), 31.3\left(\mathrm{CH}_{3}\right), 34.3\left(\mathrm{C}\left(\mathrm{CH}_{3}\right)_{3}\right), 39.4\left(\mathrm{CH}_{2}\right), 70.1$ $\left(\mathrm{OCH}_{2}\right), 71.3\left(\mathrm{OCH}_{2}\right), 119.8$ (ArC), 121.9 (ArC), 125.1 (ArC), 125.2 (ArC), 125.4 (ArC), 125.9 (ArC), 126.2 (ArC), 126.5 (ArC), 127.1 (ArC), 127.5 (ArC), 127.8 (ArC), 128.0 (ArC), 128.3 (ArC), 128.5 (ArC), 128.6 (ArC), 128.8 (ArC), 129.0 (ArC), 129.1 (ArC), 129.3 (ArC), 130.0 (ArC), 135.1 (ArC), 136.2 (ArC), 147.8 (ArC), 148.0 (ArC), 149.5 (ArC), 151.9 (ArC), 154.0 (ArC) and 158.4 (CO) ppm. FABMS: m/z: $[\mathrm{M}+\mathrm{H}]^{+}$Calcd for $\mathrm{C}_{74} \mathrm{H}_{85} \mathrm{~N}_{4} \mathrm{O}_{6} \mathrm{~S}_{4}$ (1253.5352) ; Found 1253.4812 .

$\mathbf{4}_{\mathrm{c}}$ : To a solution of compound 3 (150 $\left.\mathrm{mg}, 0.166 \mathrm{mmol}\right)$ in $\mathrm{CH}_{2} \mathrm{Cl}_{2} \quad(10 \mathrm{~mL})$ was added $p$-(trifluoromethyl)phenyl isocyanate (68 $\mathrm{mg}, 0.366 \mathrm{mmol}$ ) and the mixture was stirred at room temperature for $24 \mathrm{~h}$ under argon. The resulting precipitate was collected by filtration, washed with $\mathrm{CH}_{3} \mathrm{OH}$ to give receptor $\mathbf{4}_{\mathrm{c}}$ as a white solid. Recrystallization from $\mathrm{CHCl}_{3}-$ $\mathrm{CH}_{3} \mathrm{OH}$ (3:2) gave receptor $\mathbf{4}_{\mathrm{c}}(147 \mathrm{mg}, 65 \%)$ as a white solid. M.p. $210-211^{\circ} \mathrm{C}$. IR: $v_{\max }(\mathrm{KBr}) / \mathrm{cm}^{-1}$ : 3279, 2923, 1602, 1572, 1538, 1225, 1170, 1091, 1068, 905 and 794. ${ }^{1} \mathrm{H}$ NMR (300 $\left.\mathrm{MHz}, \mathrm{CDCl}_{3}\right): \delta=0.82(18 \mathrm{H}, \mathrm{s}, t \mathrm{Bu} \times 2), 1.19(18 \mathrm{H}, \mathrm{s}, t \mathrm{Bu} \times$ 2), $3.12\left(4 \mathrm{H}, \mathrm{br}, \mathrm{CH}_{2} \mathrm{NH} \times 2\right), 4.03\left(4 \mathrm{H}, \mathrm{br}, \mathrm{OCH}_{2} \times 2\right), 5.08$ $\left(4 \mathrm{H}, \mathrm{s}, \mathrm{OCH}_{2} \times 2\right), 5.75(2 \mathrm{H}, \mathrm{s}, \mathrm{NH} \times 2), 6.92-7.30 .(18 \mathrm{H}, \mathrm{m}$, Phenyl-H× 18), $7.13(4 \mathrm{H}, \mathrm{s}, \mathrm{Ar}-\mathrm{H} \times 4), 7.33(2 \mathrm{H}, \mathrm{s}, \mathrm{NH} \times 2)$ and $7.41(4 \mathrm{H}, \mathrm{s}, \mathrm{Ar}-\mathrm{H} \times 4) \mathrm{ppm} .{ }^{13} \mathrm{C} \mathrm{NMR}\left(100 \mathrm{MHz}, \mathrm{CDCl}_{3}\right)$ : $\delta=32.1\left(\mathrm{CH}_{3}\right), 35.6\left(\mathrm{C}\left(\mathrm{CH}_{3}\right)_{3}\right), 40.0\left(\mathrm{CH}_{2}\right), 70.1\left(\mathrm{OCH}_{2}\right), 70.9$ $\left(\mathrm{OCH}_{2}\right), 118.1$ (ArC), 118.8 (ArC), 122.2 (ArC), 122.4 (ArC), 122.7 (ArC), 122.9 (ArC), 123.0 (ArC), 123.3 (ArC), 123.6 (ArC), 124.0 (ArC), 124.4 (ArC), 124.8 (ArC), 126.1 (ArC), 126.5 (ArC), 126.8 (ArC), 127.3 (ArC), 127.8 (ArC), 128.0 (ArC), 128.7 (ArC), 129.3 (ArC), 129.5 (ArC), 138.2 (ArC), 138.9 (ArC), 149.2 (ArC), 155.2 (ArC) and 160.7 (CO) ppm. FABMS: $\quad m / z: \quad 1361.4861 \quad[\mathrm{M}+\mathrm{H}]^{+} . \quad \mathrm{C}_{74} \mathrm{H}_{79} \mathrm{~F}_{6} \mathrm{~N}_{4} \mathrm{O}_{6} \mathrm{~S}_{4}$ (1361.4787): calcd C 65.27, H 5.77, N 4.11. Found: C 65.32, H 5.75, N 4.08 .

\section{Determination of the association constants}

The association constants $\left(K_{\mathrm{a}}\right)$ were determined by using ${ }^{1} \mathrm{H}$ NMR spectroscopic titration experiments with a constant concentration of host receptor $\left(4.0 \times 10^{-3} \mathrm{M}\right)$ and varying the guest concentrations $\left(0-8.0 \times 10^{-3} \mathrm{M}\right)$. The ${ }^{1} \mathrm{H}$ NMR chemical shifts of the urea protons $(\mathrm{NH})$ signal were used as a probe. The $K_{\mathrm{a}}$ values for the complexes of receptor $\mathbf{4}_{\mathbf{a} \sim \mathrm{c}}$ were calculated by nonlinear curve-fitting analysis of the observed chemical shifts of the $\mathrm{NH}$ protons according to the literature procedure. ${ }^{13 \mathrm{a}}$

\section{${ }^{1}$ H NMR titration experiments}

A solution of $\mathrm{Bu}_{4} \mathrm{NX}\left(\mathrm{X}=\mathrm{F}, \mathrm{Cl}, \mathrm{Br}, \mathrm{I}, \mathrm{AcO}, \mathrm{H}_{2} \mathrm{PO}_{4}\right.$ ) in $\mathrm{CD}_{3} \mathrm{CN}$ $\left(4.0 \times 10^{-3} \mathrm{M}\right)$ was added to a $\mathrm{CDCl}_{3}$ solution of receptor $\mathbf{4}_{\mathbf{a} \sim \mathbf{c}}$ in an NMR tube. ${ }^{1} \mathrm{H}$ NMR spectra were recorded after addition of 
the reactants and the temperature of the NMR probe was kept constant at $27^{\circ} \mathrm{C}$.

\section{Crystallographic analyses of $\mathbf{4}_{\mathbf{a}}$}

Diffraction data were collected on a Bruker APEX 2 CCD diffractometer equipped with graphite-monochromated Mo-Ka radiation at $150(2) \mathrm{K}^{15}$ Data were corrected for Lorentz and polarisation effects and for absorption. ${ }^{15}$ The structures were solved by direct methods and refined by full-matrix least-squares methods, on $F^{2}{ }^{16}$ The asymmetric unit contains four calixarenes two chloride anions, two tetrabutylammonium cations, one chloroform and two acetonitrile molecules of crystallisation. Within each of the four calixarenes there are pairs of $\mathrm{N}-\mathrm{H} \cdots \mathrm{O}$ hydrogen bonds between urea moieties to a single carbonyl $\mathrm{O}$ atom. Looking down on the $\mathrm{S}_{4}$ square-shaped planes of the four unique calixarenes, three are approximately geometrically aligned in parallel while one, containing S(1A), is slightly twisted.

Two $t \mathrm{Bu}$ groups on calixarenes were modelled as disordered over two sets of positions for the Me groups. See tables for the occupation factors. Two $n$-butyl chains in the cations exhibit some signs of disorder, but this was not modelled. The chloroform molecule was modelled as fully disordered over two sets of positions. There are two molecules of acetonitrile of crystallisation which reside in claixarene clefts on molecules containing $S(1)$ and S(1B).

Pairs of calixarene molecules are linked via four H-bonds between both urea $\mathrm{N}-\mathrm{H}$ moieties on each calixarene and a chloride ion. $n$-butyl ammonium cations reside close to the chloride anions, due to electrostatic attraction. So, each pair of calixarenes is able to capture one chloride ion. The overall packing type is in layers.

Crystal data for $\mathbf{4}_{\mathbf{a}}$ : $\mathrm{C}_{144} \mathrm{H}_{160} \mathrm{~N}_{8} \mathrm{O}_{12} \mathrm{~S}_{8} \cdot \mathrm{C}_{16} \mathrm{H}_{36} \mathrm{~N}^{+} \cdot \mathrm{Cl}^{-} \cdot 0.5\left(\mathrm{CHCl}_{3}\right)$. $\mathrm{C}_{2} \mathrm{H}_{3} \mathrm{~N}, \mathrm{M}=2829.91$. Triclinic, space group $P^{-} 1, a=15.1315$ (5), $b$ $=28.8618$ (11), $c=35.9491$ (13) $\AA, V=15113.8$ (9) $\AA^{3} . Z=4, D c=$ 1.244 g.cm ${ }^{-3}, F(000)=6044, T=100 \mathrm{~K}, \mu(\mathrm{Mo}-\mathrm{K} \alpha)=0.226 \mathrm{~cm}^{-1}$, $\lambda(\mathrm{Mo}-\mathrm{K} \alpha)=0.71073 \AA$, colourless crystal of size $0.16 \times 0.13 \times 0.04$ $\mathrm{mm}^{3}$. The total number of reflections measured, to $\theta_{\max }=25.3^{\circ}$, was 42128 of which 27707 were unique $\left(R_{\mathrm{int}}=0.062\right)$; 8953 were 'observed' with $I>2 \sigma(I)$. For the 'observed' data only, $R_{1}=0.068$; $\mathrm{w} R_{2}=0.185$ for all 42128 reflections and 3705 parameters. Residual electron density within $+/-0.86 \mathrm{e} \AA^{-3}$.

Crystallographic data (excluding structure factors) for the structures in this paper have been deposited with the Cambridge Crystallographic Data Centre as supplementary publication number CCDC 1062186 for $\mathbf{4}_{\mathbf{a}}$. Copies of the data can be obtained, free of charge, on application to CCDC, 12 Union Road, Cambridge CB2 1EZ, UK [fax: 144-1223-336033 or e-mail: deposit@ccdc.cam.ac.uk].

Supporting information: ${ }^{1} \mathrm{H},{ }^{13} \mathrm{C}$ NMR \& IR spectra of compounds $\mathbf{2}, \mathbf{3}$ and $\mathbf{4}_{\mathrm{a} \sim \mathrm{c}}$.

\section{Acknowledgements}

This work was performed under the Cooperative Research Program of "Network Joint Research Center for Materials and Devices (Institute for Materials Chemistry and Engineering, Kyushu University)”. We would like to thank the OTEC at
Saga University and the International Cooperation Projects of Guizhou Province (No. 20137005) for financial support. CR thanks the EPSRC for a travel grant. The computational work has been assisted by the use of computing resources provided by WestGrid and Compute/Calcul Canada. We thank Dr. Grigory Shamov, Westgrid/U. Manitoba for support.

\section{Notes and references}

1 (a) C. D. Gutsche, Calixarenes, An Introduction, Royal Society of Chemistry: Cambridge, UK, 2008; (b) A. Ikeda and S. Shinkai, Chem. Rev., 1997, 97, 1713-1734; (c) D. Coquière, S. Le Gac, U. Darbost, O. Sénèque, I. Jabin and O. Reinaud, Org. Biomol. Chem., 2009, 7, 2485-2500; (d) K. Cottet, P. M. Marcos and P. J Cragg, Beilstein, J. Org. Chem. 2012, 8, 201-226; (e) L. Mutihac, J. H. Lee, J. S. Kim and J. Vicens, Chem. Soc. Rev., 2011, 40, 2777-2796; (f) L. Baldini, A. Casnati, F. Sansone and R. Ungaro, Chem. Soc. Rev., 2007, 36, 254-266; (g) J. S. Kim and D. T. Quang, Chem. Rev., 2007, 107, 3780-3799; (h) R. Joseph and C. P. Rao, Chem. Rev., 2011, 111, 4658-4702; (i) C. Capici, Y. Cohen, A. D'Urso, G. Gattuso, A. Notti, A. Pappalardo, S. Pappalardo, M. F. Parisi, R. Purrello, S.Slovak and V. Villari, Angew. Chem., Int. Ed., 2011, 50, 12162-12167; (j) C. Talotta, C. Gaeta1, Z. Qi, C. A. Schalley and P. Neri, Angew. Chem., Int. Ed., 2013, 52, 7437-7441; (k) M.-X. Wang, Acc. Chem. Res., 2012, 45, 182-195.

2 (a) H. Kumagi, M. Hasegawa, S. Miyanari, Y. Sugawa, Y. Sato, T. Hori, S. Ueda, H. Kamiyama and S. Miyano, Tetrahedron Lett., 1997, 38, 3971-3972.

3 (a) P. Lhoták, Eur. J. Org. Chem., 2004, 1675-1692; (b) N. Morohashi, F. Narumi, N. Iki, T. Hattori and S. Miyano, Chem. Rev., 2006, 106, 5291-5316; (c) R. Kumar, Y.-O. Lee, V. Bhalla, M. Kumar and J.-S. Kim, Chem. Soc. Rev., 2014, 43, 4824-4870.

4 (a) P. D. Beer and P. A. Gale, Angew. Chem. Int. Ed., 2001, 40, 486-516; (b) T. Nabeshima, T. Saiki and S. Kumitomo, Org. Lett., 2002, 4, 3207-3209; (c) T. Nabeshima, Y. Yoshihira, T. Saiki, S. Akine and E. Horn, J. Am. Chem. Soc., 2003, 125, 28-29; (d) A. Y. Zhukov, T. A. Fink, I. I. Stoikov and I. S. Antipin, Russ. Chem. Bull., Int. Ed., 2009, 58, 1007-1014; (e) K. Mohr, J. Schmitz, R. Schrage, C. Trnkle and U. Holzgrabe, Angew. Chem. Int. Ed., 2013, 52, 508-516; (f) R. Nussinov and C.-J. Tsai, Cell, 2013, 153, 293-305.

5 (a) H. Lu, W. Xu, D. Zhang, C. Chen and D. Zhu, Org. Lett., 2005, 7, 4629-4632; (b) F. M. Pfeffer, T. Gunnlaugsson, P. Jensen and P. E. Kruger, Org. Lett., 2005, 7, 5357-5360; (c) L. Fang, W.-H. Chan, Y.-B. He, D. W.-J. Kwong and A. W.-M. Lee, J. Org. Chem., 2005, 70, 7640-7646; (d) T. Gunnlaugsson, P. E. Kruger, P. Jensen, J. Tierney, H. D. Paduka Ali and G. M. Hussey, J. Org. Chem., 2005, 70, 10875-10878; (e) A. Dahan, T. Ashkenazi, V. Kuznetsov, S. Makievski, E. Drug, L. Fadeev, M. Bramson, S. Schokoroy, E. Rozenshine-Kemelmakher and M. Gozin, J. Org. Chem., 2007, 72, 2289-2296; (f) S. Saha, A. Ghosh , P. Mahato , S. Mishra , S. K. Mishra, E. Suresh , S. Das 
and A. Das, Org. Lett., 2010, 12, 3406-3409; (g) S. Kondo, M. Nagamine, S. Karasawa, M. Ishihara, M. Unno and Y. Yano, Tetrahedron, 2011, 67, 943-950; (h) M. Alešković, N. Basarić, I. Halasz, X. Liang, W. Qin and K. Mlinarić-Majerski, Tetrahedron, 2013, 69, 1725-1734; (i) S. Lee, Y. Hua and A. H. Flood, J. Org. Chem., 2014, 79, 8383-8396; (j) Y. Jo, N. Chidalla and D.-G. Cho, J. Org. Chem., 2014, 79, 9418-9422; (k) F. Zapata, A. Caballero, P. Molina, I. Alkorta and J. Elguero, J. Org. Chem., 2014, 79, 6959-6969.

(a) J. L. Sessler, P. A. Gale and W. S. Cho, Anion Receptor Chemistry; Royal Society of Chemistry: Cambridge, U.K., 2006; (b) P. D. Beer, P.A. Gale, Angew. Chem., Int. Ed., 2001, 40, 486-516.

7 (a) J. F. Zhang, Y. Zhou, J. Yoon and J. S. Kim, Chem. Soc. Rev., 2011, 40, 3416-3429; (b) C. Lodeiro, J. L. Capelo, J. C. Mejuto, E. Oliveira, H. M. Santos, B. Pedras and C. Nuñez, Chem. Soc. Rev., 2010, 39, 2948-2976; (c) L. E. SantosFigueroa, M. E. Moragues, E. Climent, A. Agostini, R. Martínez-Máñez and F. Sancenón, Chem. Soc. Rev., 2013, 42, 3489-613; (d) C. Pérez-Casas and A. K. Yatsimirsky, J. Org. Chem., 2008, 73 (6), 2275-2284.

8 (a) J. P. Clare, A. Statnikov, V. Lynch, A. L. Sargent and J. W. Sibert, J. Org. Chem., 2009, 74, 6637-6646; (b) Q.-S Lu, L. Dong, J. Zhang, J. Li, L. Jiang, Y. Huang, S. Qin, C.-W. Hu and X.-Q. Yu, Org. Lett., 2009, 11, 669-672; (c) S. Goswami, D. Sen and N. K. Das, Org. Lett., 2010, 12, 856859; (d) A. Aldrey, C. Nứñez, V. García, R. Bastida, C. Lodeiro, A. Macías, Tetrahedron, 2010, 66, 9223-9230; (e) P. Dydio, T. Zieliński and J. Jurczak, Org. Lett., 2010, 12, 1076-1078; (f) V. K. Bhardwaj, S. Sharma, N. Singh, M. S. Hundal and G. Hundal, Supramol. Chem., 2011, 23, 790800; (g) G.-W. Lee, N.-K. Kim and K.-S. Jeong, Org. Lett., 2011, 13, 3024-3027; (h) H. M. Chawla, S. N. Sahu, R. Shrivastava, S. Kumar, Tetrahedron Lett., 2012, 53, 2244 2247; (i) S. Goswami, A. Manna, S. Paul, K. Aich, A. K. Das and S. Chakraborty, Tetrahedron Lett., 2013, 54, 17851789; $(j)$ K. Pandurangan, J. A. Kitchen and T. Gunnlaugsson, Tetrahedron Lett., 2013, 54, 2770-2775; (k) S. Areti, J. K. Khedkar, R. Chilukula and C. P. Rao, Tetrahedron Lett., 2013, 54, 5629-5634; (l) C. Jin, M. Zhang, C. Deng, Y. Guan, J. Gong, D. Zhu, Y. Pan, J. Jiang and L. Wang, Tetrahedron Lett., 2013, 54, 796-801; (m) P. M. Marcos, F. A. Teixeira, H. Kooijman, M. A. P. Segurado, J. R. Ascenso, R. J. Bernardino, S. Michel and V. HubscherBruder, J. Org. Chem., 2014, 79, 742-751; (n) E. Brunetti, J.-F. Picron, K. Flidrova, G. Bruylants, K. Bartik and I. Jabin, J. Org. Chem., 2014, 79, 6179-6188.

9 (a) J. Kroupa, I. Stibor, M. Pojarová, M. Tkadlecová and P. Lhoták, Tetrahedron, 2008, 64, 10075-10079; (b) O. Kundrat, H. Dvorakova, I. Cisarova, M. Pojarova and P. Lhoták, Org. Lett., 2009, 11, 4188-4191; (c) O. Kundrat, I. Cisarova, S. Böhm, M. Pojarova and P. Lhoták, J. Org. Chem., 2009, 74, 4592-4596; (d) O. Kundrat, H. Dvorakova, V. Eigner and P. Lhoták, J. Org. Chem., 2010, 75, 407-411; (e) O. Kundrat, J. Kroupa, S. Böhm, J. Budka, V. Eigner and P. Lhoták, J. Org. Chem., 2010, 75, 8372-8375; (f) O.
Kundrát, V. Eigner, P. Cuř́nová, J. Kroupa and P. Lhoták, Tetrahedron, 2011, 67, 8367-8372; (g) O. Kundrat, V. Eigner, H. Dvorakova, and P. Lhoták, Org. Lett., 2011, 13, 4032-4035; (h) P. Slavik, M. Dudic, K. Flidrova, J. Sykora, I. Cisarova, M. Pojarova and P. Lhoták, Org. Lett., 2012, 14, 3628-3631; (i) O. Kundrat, H. Dvorakova, S. Böhm, V. Eigner and P. Lhoták, J. Org. Chem., 2012, 77, 2272-2278; (j) M. Mačková, M. Himl, J. Budka, M. Pojarová, I. Císařová,, V. Eigner, P. Cuř́nová, H. Dvořáková and P. Lhoták, Tetrahedron, 2013, 69, 1397-1402; (k) J. Lukášek, S. Böhm, H. Dvořáková, V. Eigner and P. Lhoták, Org. Lett., 2014, 16, 5100-5103.

10 J. N. Babu, V. Bhalla, M. Kumar, R. K. Mahajan and R. K. Puri, Tetrahedron Lett., 2008, 49, 2772-2775.

11 (a) C. Perez-Casas and T. Yamato, J. Incl. Phenom. Macrocyclic Chem., 2005, 53, 1-8; (b) T. Yamato, C. PerezCasas, H. Yamamoto, M. R. J. Elsegood, S. H. Dale and C. Redshaw, J. Incl. Phenom. Macrocyclic Chem., 2006, 54, 261269; (c) C. Perez-Casas, S. Rahman, N. Begum, Z. Xi and T. Yamato, J. Incl. Phenom. Macrocyclic Chem., 2008, 60, 173185; (d) X.-L. Ni, H. Tomiyasu, T. Shimizu, C. Perez-Casas, X. Zeng, and T. Yamato, J. Incl. Phenom. Macrocyclic Chem., 2010, 68, 99-108; (e) X.-L. Ni, X. Zeng, C. Redshaw and T. Yamato, J. Org. Chem., 2011, 76, 3358-3370; (f) X.-L. Ni, X. Zeng, C. Redshaw and T. Yamato, Tetrahedron, 2011, 67, 3248-3253; (g) X.-L. Ni, J. Tahara, S. Rahman, X. Zeng, D. L. Hughes, C. Redshaw and T. Yamato, Chem. Asian. J., 2012, 7, 519-527; (h) X.-L. Ni, H. Cong, A. Yoshizawa, S. Rahman, H. Tomiyasu, U. Rayhan, X. Zeng and T. Yamato, J. Mol. Struct., 2013, 1046, 110-115; (i) H. Tomiyasu, C.-C. Jin, X.-L. Ni, X. Zeng, C. Redshaw, T. Yamato, Org. Biomol. Chem., 2014, 12, 4917-4923; (j) H. Tomiyasu, N. Shigyo, X.-L. Ni, X. Zeng, C. Redshaw and T. Yamato, Tetrahedron, 2014, 70, 7893-7899.

12 C. Perez-Casas, H. Hopfl, A. K. Yatsimirsky, J. Incl. Phenom. Macrocyclic Chem., 2010, 68, 387-398.

13 (a) L. Fielding, Tetrahedron, 2000, 56, 6151-6170; (b) H. A. Benesi and J. H. Hildebrand, J. Am. Chem. Soc., 1949, 71, 2703-2707.

14 M. J. Frisch, G. W. Trucks, H. B. Schlegel, G. E. Scuseria, M. A. Robb, J. R. Cheeseman, G. Scalmani, V. Barone, B. Mennucci, G. A. Petersson, H. Nakatsuji, M. Caricato, X. Li, H. P. Hratchian, A. F. Izmaylov, J. Bloino, G. Zheng, J. L. Sonnenberg,; M. Hada, M. Ehara, K. Toyota, R. Fukuda, J. Hasegawa, M. Ishida, T. Nakajima, Y. Honda, O. Kitao, H. Nakai, T. Vreven, Jr. J. A. Montgomery, J. E. Peralta, F. Ogliaro, M. Bearpark, J. J. Heyd, E. Brothers, K. N. Kudin, V. N. Staroverov, T. Keith, R. Kobayashi, J. Normand, K. Raghavachari, A. Rendell, J. C. Burant, S. S. Iyengar, J. Tomasi, M. Cossi, N. Rega, J. M. Millam, M. Klene, J. E. Knox, J. B. Cross, V. Bakken, C. Adamo, J. Jaramillo, R. Gomperts, R. E. Stratmann, O. Yazyev, A. J. Austin, R. Cammi, C. Pomelli, J. W. Ochterski, R. L. Martin, K. Morokuma, V. G. Zakrzewski, G. A. Voth, P. Salvador, J. J. Dannenberg, S. Dapprich, A. D. Daniels, O. Farkas, J. B. Foresman, J. V. Ortiz, J. Cioslowski, D. J. Fox, Gaussian 09, Revision D.01; Gaussian, Inc., Wallingford CT, 2013.

15 SAINT and APEX 2 (2008) software for CCD diffractometers. Bruker AXS Inc., Madison, USA 
16 G. M. Sheldrick, Acta Crystallogr., 2008, A64, 112-122. 